\title{
高分解能透過電子顕微鏡の現在と今後
}

\author{
名古屋大学未来材料システム研究所 田中信夫
}

\section{Nobuo TANAKA: Present Status and Future Prospects of HRTEM}

This report reviews recent progress of HRTEM since the previous review in the present journal in 2014 and discusses the future prospects. Particular topics are development of electron energy loss spectroscopy, time-resolved measurement and a new phase imaging method and single particle analysis of proteins.

\section{1. はじめに}

高分解能透過電子顕微鏡法(HRTEM)の進歩については

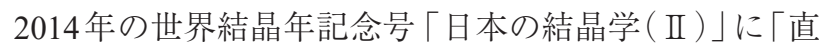
接観察法の技術的進展」の題で寄稿した。ここではそれ 以後の進歩について我が国の成果を中心に紹介したい.

\section{2. 分解能の到達点 一TEM から STEMへ—}

この 10 年間に透過電子顕微鏡（TEM）の明視野像の 点分解能は $60 \mathrm{pm}$ 程度に達したがそれ以上は立ち止まっ ている.この理由として原子散乱因子の高角側の低下の ためという説明がある (Lentzen). TEM は散乱（回折） 波を対物レンズにより集めフーリエ合成で点像にするた めに, 高角側の低下は実空間では像のボケとなる。これ までは対物レンズの主に球面収差によりこのボケが生 じて分解能の限界を与えていたが, 21 世紀に入り磁場レ ンズの収差補正技術が実用化し光学装置としては $50 \mathrm{pm}$ 以下の分解能が得られるようになった。

近年は $100 \mathrm{pm}$ 以下の電子プローブで試料を二次元的 に走査し一点一点からの散乱電子強度を表示することで 顕微鏡像を得る円環状検出走査透過電子顕微鏡 (ADFSTEM）が主流になってきた. STEMではレンズによる フーリエ合成に頼らず，テレビの撮像および再生と同 様, 一点一点ずつ像を作っていくので, 現代のデジタル 技術とも相性がよい. STEMの点分解能はTEMのそれを 凌ぎ $40.5 \mathrm{pm}$ に達している. ${ }^{1)}$ その分解能の証明には $\mathrm{GaN}$ 結晶を [212]方向から見たときの隣接する $\mathrm{Ga}$ 原子コラム 像の分離を用いている(図1). また支持膜の上に置かれ た金や白金，銀の単原子は1970年に同じくADF-STEM 法で観察されてしまっている(Crewe).

収差補正技術の進展によって200〜300 kVの電圧で 加速された電子は $50 \mathrm{pm}$ 以下のプローブにすることがで きる. 原子の大きさをイオン半径の 2 倍程度 ( 擬クー ロンポテンシャルの大きさ) と考えると $0.2 \mathrm{~nm}$ なので 日本結晶学会誌 第 62 巻 第 3 号 $(2020)$

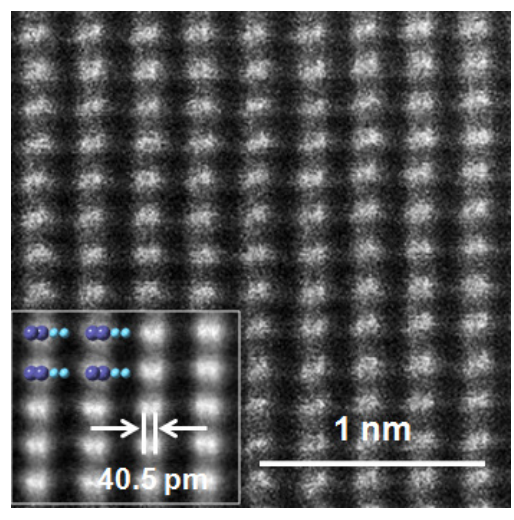

図1 GaN結晶の [212］方向からの暗視野STEM像.1) (Annular dark field STEM image of GaN at [212] direction.) (森下氏のご好意による)

その $1 / 4 く ら い の$ 細い電子線で原子を走査している状態 である.

このような極限的な観察が商用機で可能になったの は, 電気的, 機械的安定度が十分進み, かつ試料の静止 状態が 1 分間以上保たれることや, 極細電子線の走査が 精確に行われるようになったことが理由である.

\section{3. 結合電子の顕微鏡観察は可能か?}

$40 \mathrm{pm}$ 程度の間隔の原子コラム像観察が成功している 現在, 電子顕微鏡法の次の目標の 1 つは結晶中の結合電 子の情報を可視化することであろう. 結合電子の可視化 についてはすでにX線回折や収束電子回折 (CBED) を 使った研究があるが, それは数 $\mu \mathrm{m}$ や数 $10 \mathrm{~nm}$ の試料領 域の平均的な構造情報である。顕微鏡法で単位胞内の 結合電子の情報が得られれば, それは大きな進歩となる であろう。

周知のように観察試料を構成する原子の原子核は格 子振動している. 原子核と周辺電子が作り出す擬クーロ ンポテンシャルはその分だけぼけている。この原子核の 振動効果をガウス分布型のデバイ温度因子として取り入 
れることはよく知られている.

$\mathrm{X}$ 線回折のほうは原子核周りの電子分布のみを可視化 しているので, これをデバイ因子でぼかしておけばよい. 電子線の場合は少し拡がったクーロン場と, もう1つの 非局在性をもちこむデバイ因子が可視化のボケの原因を 作りだす。ここで, 電子の散乱にとって補正項である電 荷分布の情報を正確に抜き出せるかは, 今後の研究の進 展を待たなければならないだろう。

もちろん単位胞内のポテンシャル分布は核の正電荷と 周辺電子の負電荷分布とポアソン方程式でつながってい るので, TEMで投影ポテンシャル分布が得られれば数值 積分操作で周辺電子の電荷分布の投影を得ることは原 理的には可能である.これはモット $(\mathrm{Mott})$ の式として 知られるものである。しかしここに温度因子が既知であ ることが必要になる.ナノ電子回折や電子顕微鏡を使っ て原子周辺の電荷分布の詳細情報を得るには, 局所局 所の温度因子の問題を避けて通るわけにはいかない.

\section{4. 非弾性散乱波を使った TEM 像}

昨今の半導体ピクセル検出器の進歩により弾性散乱 波の 1/10～1/100 以下の強度の非弾性散乱波を使っても, 原子レベルの電子構造の解析や, 元素分布や物理状態 分布のマップが得られるようになってきた. 非弾性散乱 に伴う損失エネルギーを弁別したフィルター像はTEM 法とSTEM法で可能であるが，原子レベルのマッピング は最近はSTEM法でなされている。

ここで本質的に問題になるのが, STEMの0.1 nm以下 の電子プローブで試料の局所を励起したときに, それに よる二次散乱過程を作りだす空間広がりの大きさであ る. ${ }^{2)} こ れ は 1980$ 年代から研究されているが, 損失エネ ルギーが大きくなればその局在性は増す (Egerton). 古 くはBetheの研究もあるが, 例えばシリコンの $\mathrm{L}_{23}$ 吸収 端を使った結像だと $0.6 \mathrm{~nm}$ 程度の拡がりとなる. STEMEELSを使った原子コラム組成マッピングだと, チャネ リング (多重回折) 効果により非弾性散乱電子もコラム 直下で局在していることもある. 原子レベルの非弾性散 乱の局在性を実測するためには, 適切な試料構造を選ば ねばならない。

電子線の非弾性散乱過程はX線の放出を伴っても起 こる。このX線エネルギーを解析するとEELS と対照的 に試料のエネルギー始状態の情報が得られる。これまで はエネルギー分散型分光器が主流であったが, 寺内ら はTEMにも使える波長分散型分光器を開発して分解能 $80 \mathrm{meV}$ を実現した.33

\section{5. 高速電子線による格子振動の研究}

2015 年以後のEELSにおける大きな進展は, エネル ギー分解能が数 meVにまで小さくなったことである.

176
これまでのEELSのエネルギー分解能は電子銃からの 放出電子のエネルギー幅である $0.2 \mathrm{eV}$ 程度であったが, STEMの電子銃の後にエネルギー単色器をつけること によって数 meVが実現した．実験のプローブ径はまだ 原子コラムレベルにはなっていないが, 有機結晶のフォ ノンモードの分別ができるところまできている（Rez）. また明確な晶癖がある結晶中の種々のプラズモンモー ドの局在化がその持続時間も含めて可視化されている (Batson)。また運動量空間を分解してのEELS も標準的 に行われている.

このような高エネルギー分解能の測定は1970年初頭 にGeigerらによってすでに行われているが, そのとき は入射電子波が広い平面波だった。これが数 $\mathrm{nm}$ 程度の STEM電子線プローブを励起源として得られているとこ ろに大きな進展がある。

\section{6. パルス電子線を使ったTEMの進展}

TEM観察で残っている測定パラメータとして時間軸 がある。これまでは高感度TVのフレームを1/60秒から さらに短くする試みが種々なされてきた. 近年は放出電 子線をパルス化して, この時間間隔に同期させて種々の 測定をする「パルス電子回折および顕微鏡法」が開発さ れている。この領域で大きな成果を残したのはカルフォ ルニア工科大のZewailである. 彼はこの技術を TEM 観 察にも応用しパルス電子線を使って炭素ナノチューブ の励起の軸方向への伝播をEELSを使って測定してい る. またローレンスリバモア研究所のグループは, 単発 型のパルス電子で金属薄膜内の non-reversible現象を観 察している (LaGrange).

日本では名大, 京大, 阪大を中心として装置開発が進 み, 加速電圧が $30 \mathrm{kV}$ から $1,000 \mathrm{kV}$ 以上の超高圧のパル 久電子回折装置が存在する。単発型の場合, 高倍率像を 得るためには明るい照射が必要で, 1つのパルスに多数 の電子を詰め込む必要がある。そうするとクーロン反発 効果で個々の電子のエネルギー幅が広がってしまうと いう险路に遭遇する。したがって弱い照射を繰り返し行

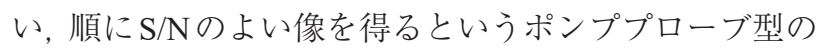
方法が標準的である。これには現象が励起光などによっ て高速で reversibleでなくてはならない.

\section{7. スピン偏極電子線を使ったTEMの開発}

パルス TEM でユニークなものは名大の桑原らによる スピンが $90 \%$ 以上偏極したパルス電子による TEMであ る (図2).4) 電子源は高融点金属の針ではなく GaAs/AlAs 系歪超格子の平面状結晶を使っている，ただし偏極した 電子のスピンと試料中の磁場ベクトルとの相互作用は通 常の TEM で使う静電場との相互作用と較べ格段に小さ く, 偏極スピン電子を用いて原子レベルの磁化分布像を 


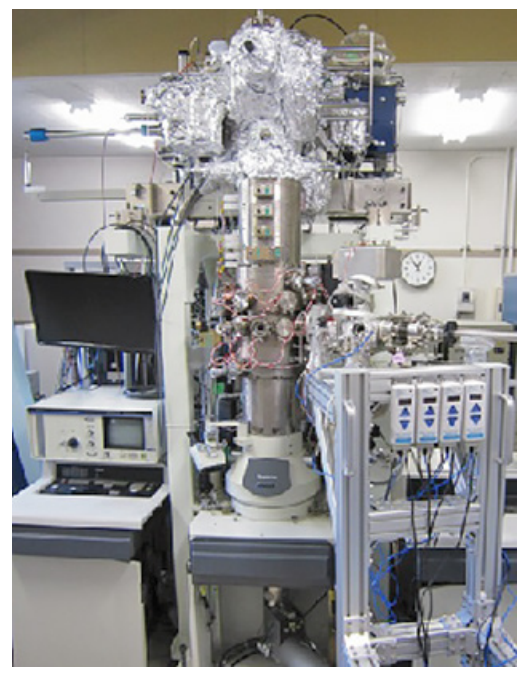

図2 名古屋大学で開発された入射電子がスピン偏極し ているパルス $\operatorname{TEM}(\mathrm{E}=20 \sim 40 \mathrm{kV}){ }^{4}$ ) (Pulse-TEM using spin-polarized electrons developed at Nagoya University ; $(\mathrm{E}=20 \sim 40 \mathrm{kV})$.)

得るには装置の安定度やデー夕収集について抜本的な 改善が必要である。いずれにしても，このような研究に よって従来は異分野であったパルスレーザー分光法と 原子を観察する TEM 法が研究者層としても結合する状 況となっている.

\section{8. 電子波の位相計測 一ホログラフィーー}

ついで, 試料を透過した電子の位相計測の進展につい て記す。この領域では1960年代から極細ワイヤを使っ たMollenstedt型バイプリズムを使った電子線ホログラ フィーが知られている。この10年間の主なる研究は結 晶の平均内部電位 $\mathrm{V}_{0}$ による位相変化を測定して半導体 や電池電極界面の電位変化を観察することやスカルミ オンなどの微小磁性体の観察である。原子間隔の情報を 与える Vgをも取りこんだ原子レベルホログラフィーは ドイツのLichteらが行っているが, 通常のTEM PTEM の以上の新しい情報が得られているわけではない.

ホログラフィーの実験手法では日立の谷垣らが複数の バイプリズムを使い, 干渉領域をバイプリズムのワイヤ の両側から離れた場所にも設定できるようにしたことは 今後の新しい実験のきっかけとなると考えられる.5)試 料傾斜法を使った試料中の電場と磁場ベクトルの分離, およびその三次元再構成の研究もある.5) またパナソニッ クの野村らによる電池電極に外部電位をかけたときの ポテンシャル場の漏れをなくした試料作製技術も特筆さ れる.6)

\section{9. 微分位相コントラスト法の発展}

2012 年の柴田の研究以来 ${ }^{7)}$ 新しく 1 つの研究領域を 形成したのは高分解能 STEM を使った微分位相コントラ 日本結晶学会誌 第62 巻 第3 号 (2020)

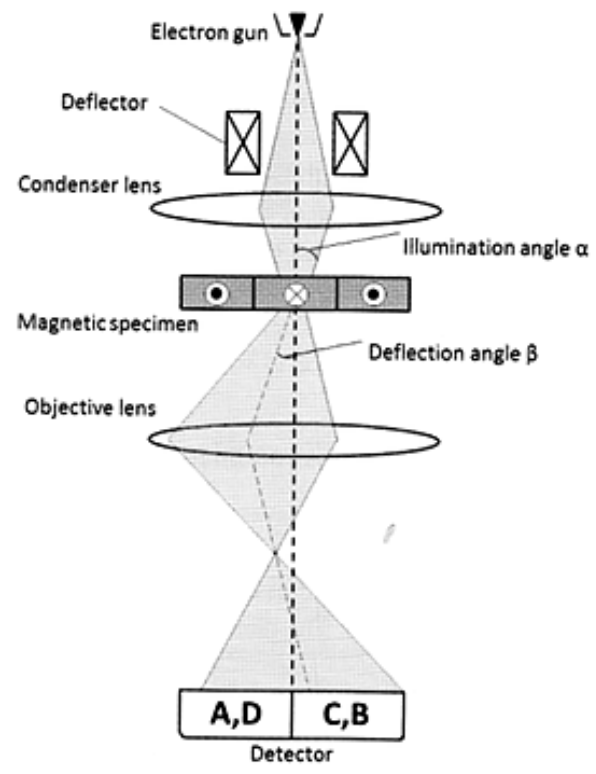

図3 微分位相コントラスト STEM 法の原理図. ${ }^{8), 19)}$

(Principle of differential phase contrast STEM.)

ス法 (Differential phase contrast; DPC), それも単位胞の 中の電場を可視化する方法の研究である.この方法は実 験的にはオランダのFEI技術者や英国のChapmanら, 理 論的にはドイツの Roseが1970年代に研究発表していた がしばらくは顕微鏡研究者によって忘れられていた。こ の間日本では日立の高橋8)により，1990年代に図3のよ うな試料下に置かれた円盤状分割型検出器を用い A D D 信号の演算により試料の磁場ベクトルの DPC 観察が行 われていたことは記しておきたい.

柴田らは $\mathrm{SrTiO}_{3}$ 単結晶を用い, 収差補正した極細電 子プローブをこの単位胞の中に入射し, 試料下にでてき た「屈折」した電子を動径方向 4 分割, 方位角方向 4 分 割の検出器を用いて検出し, その加減演算によって像コ ントラストを得て, それが投影された電場分布にあたる ことを発表した.7) 以後, 欧州の研究者もこの方法の研究 に取り組み, 2020年の現在では商品化もされ, また実験 データから電場や電荷分布を求めるソフトも実用化さ れている. また結像理論としては, 古典的な電子の屈曲 現象をエーレンフェストの定理により量子論として対応 させる考え ${ }^{9)}$ や, フーリエ光学理論と同様な展開がある (Lazic).

初期には試料下のCBED図形の電場磁場による横ズ レという言葉でこのコントラストの成因が議論された が, 上記のフーリエ光学理論によって CBED の回折円 板の「強度分布の重心の移動」という量が定量解析に重 要なポイントになることが明らかにされた

磁場ベクトルの観察法としては1970年代から TEMの ローレンツ法が標準的な方法として知られているが, 焦 点はずれ像を使うためと, 試料近傍には対物レンズの 強い磁場が及ばないような必要条件によって分解能が 
数 $10 \mathrm{~nm}$ 以上に止まっていた，現在では収差補正 TEM 法やSTEMローレンツ法が試みられ, その分解能は約 $0.6 \mathrm{~nm}$ に達している.10) このローレンツ STEM法に関連 して柴田らによる試料近傍無磁場対物レンズの開発 ${ }^{11}$ は今後の TEM 観察技術にとって重要な要素となるであ 万う.

\section{0. 環境TEM 技術の発展}

この 10 年間でもう 1 つの注目されたTEM観察技術は, 試料周りをガス雲囲気などの環境にして原子レベルの動 的観察ができるようになったことである。この方法は以 前はin-situ観察といわれていたが, 最近は環境電子顕微 鏡法 (E-TEM) と呼ばれている。ここで「環境」とは以前 から行われていた「試料加熱」や「機械的変形」に加え, 「ガス雲囲気」や「液体中試料の観察」および「電流, 磁 場印加」などを意味している。

1990 年代までは電子が通過する入口出口がある開放 型のセルが使われたが, $\mathrm{Si}_{3} \mathrm{~N}_{4}$ の薄膜が半導体技術で自 由に使えるようになって以来, 閉鎖型の環境ホルダーも 商用化され, 触媒反応, 電池電極反応の研究に多用され るようになった (Creemer)，ただ閉鎖型はガスや液体を 入れるセルの厚さが $100 \mathrm{~nm}$ 以上もあり, 透過電子線がそ の過程で非弾性散乱し色収差が生じ, 像分解能は $10 \mathrm{~nm}$ 以上であることが多い.一方開放型は米国, 英国や日本で 開発され200 300 kV 級の TEMでは収差補正技術も合 わさってガス触媒反応が原子分解能で観察されている. ${ }^{12}$

名古屋大学では 1 MV の超高圧電子顕微鏡に開放型の ガス環境セルが取り付けられ, 各種の触媒反応や, 水素 ガス中での金属脆性の研究がなされている.13) 超高電圧 で加速された電子は厚いガス中も十分透過して試料の 鮮明な像コントラストを与えている。

\section{1. 電子線トモグラフィーの発展}

電子線トモグラフィーについては 1970 年代初頭に人体 への X線 CTが開発されて以来その電顕版が試みられて きた. 主なる課題は試料の全回転ができないことから生 ずる Missing wedge 問題をどのように回避するかであっ た（Frank），それまでの画像処理方法を援用して種々の ソフトウェアが作られた。 また暗視野STEM法やTEMの 位相コントラスト法のほかにEELS やEDX信号を使った トモグラフィーも研究された。

最近の進展としては, 三次元トモグラフィーも原子分 解能になったことである. 最初はX線回折を専門とする カリフォルニア大学の Miao らが種々の角度から撮影さ れたADF-STEM像を強引にフーリエ投影定理に基づく ソフトに入れて金微粒子の内部双晶構造を三次元可視 化した。しかしADF-STEM像でもその像コントラストに は投影近似によらない非線形な要素があるので, その有
効性は完全に承認されているわけではない，日本でも九 大の研究者らが公開されているソフトを使って, 棒状金 微粒子の原子配列の三次元再構成のデー夕を発表して いる.

\section{2. バイオ試料観察用 TEM 位相板の開発}

最近のバイオ電子顕微鏡で重要な進展の 1 つは「位相 板」の実用化である. 生物試料はほぼ完全な位相物体な ので, 何らかの位相板が開発されないと, 染色して観察 するしかなかった. 1990年代に永山らが薄いカーボン膜 の真ん中にFIBを使って細孔をあけ, 周辺カーボン膜の 厚さを使って回折波の位相を変化させる位相板を開発 して生物試料の像のコントラストを上げる試みをした. ${ }^{14}$ しかし孔の周辺につくコンタミが原因するチャージ現象 が発生し長期間の使用には耐えられなかった。また観察 中の位相変化の調整もできなかった. 一方Danevらは逆 転の発想で, 薄いカーボン膜の中央部分に事前に電子 線を収束させ,コンタミまたはチャージ量を調整するこ とによって, 生物試料観察用の「Volta位相板」を実現し ている. 後述する単粒子解析法にもこの位相板が必須の ものとなっている.

\section{3. 蛋白質分子の単粒子解析法の確立}

バイオ方面でのこの 10 年の最も大きな進展は 2017 年 度のノーベル賞の対象になった「蛋白質分子の単粒子解 析法の確立」である。この方法の確立には次のような複 数の技術的進展が組み合わされている. (1) 1 個 1 個の蛋 白質分子を非晶質水薄膜に閉じ込めて試料にする, (2)前 記した位相板で無染色の分子からコントラストのある像 を得る, (3) 1 回の撮影で 10 万個以上の分子の像を TV力 メラで収集し, 方向などを揃えて整理する, (4)事前に分 子モデルの種々の傾斜電顕像を計算し, 実験で得られた 像と計算機が自動でフィッティングをする. (5)ダメージ を減らすために試料を液体へリウム冷却して低照射量で 観察できるクライオ電子顕微鏡と高感度単電子検出器の 開発，などである。

単粒子解析法では多数の分子は氷薄膜中にランダム な方向で閉じ込められているので, 原理的には 1 枚の像 から三次元再構成ができることになる，すなわち試料傾 斜ホルダーが不要である。この「単粒子解析法」の画像 解析ソフトは英国 MRC 研究所の若手 (Scheres) によっ て書かれ “RELION”として公開されて扔り誰でも使う ことができる.我が国でも顕微鏡学会主催でその利用説 明会が開催されており, 国内にも複数台のクライオ電子 顕微鏡の設置によって研究レベルはようやく世界と肩を 並べられるようになった。 


\section{4. おわりに}

今回は透過電子顕微鏡技術についてこの 10 年の進歩 を概観したが, 電子線を使った回折手法にも種々の進展 が見られる。

従来から行われていた収束電子回折による精密構造解 析では回折強度の精密測定のために磁場偏向型エネル ギーフィルターを使って, 損失エネルギ $1 \sim 20 \mathrm{eV}$ のプラ ズモン強度の除去が行われている. ${ }^{15}$

また回折強度だけから穾空間の二次元構造情報 (静電 場分布）を出す研究も世界中で行われており Diffractive imaging と呼ばれている. 我が国でも電子線 16) やX線 ${ }^{17)}$ の方々の研究がある. また位相問題解決のために, 収束 電子回折図形の重なり部分の強度分布を使うことも試み られ Ptychography と呼ばれている (Rodenburg, Nellist).

電子線の実験手法は日進月歩であり, すでに 1 個 1 個 の電子の検出器も商品化され, 計測法としては光子 1 個 1個を検出するX線回折の手法と同じレベルに達してい る. 今後は高分解能電子顕微鏡分野でも $\mathrm{AI}$ や高度な統 計処理も含めた実験結果がでることが期待される.18),19)

\section{文 献}

(我が国の研究者のものに限定させていただいた)

1) S. Morishita et al.: Microscopy 67, 46 (2018).

2) K. Kimoto et al.: Nature 450, 702 (2008).

3) M. Terauchi et al.: Microsc. Microanal. 22, 70 (2016).

4) M. Kuwahara et al.: Appl. Phys. Lett. 101, 033102 (2012).
5) T. Tanigaki et al.: J. Phys., D 24, 244001 (2016).

6) Y. Nomura et al:: Microscopy 67, 178 (2018).

7) N. Shibata et al.: Nature Physics. 8, 611 (2012).

8) Y. Takahashi et al.: Jap. J. Appl. Phys. 33, L1352 (1994).

9) T. Seki at al.: Ultramicroscopy 182, 258 (2017).

10) T. Nagai et al.: Phys Rev. B 96, 100405 (2017).

11) N. Shibata et al.: Nature Com. 10, 2303 (2019).

12) S. Takeda et al.: Microscopy 62, 193 (2013).

13) N. Tanaka et al:: Microscopy 62, 205 (2013).

14) K. Nagayama: Microscopy 60, S43 (2011).

15) K. Tsuda et al.: Phys. Rev., B 86, 214106 (2012).

16) J. Yamasaki et al.: Jap. J. Appl. Phys. 58, 120302 (2019).

17) Y. Nishino et al.: Phy. Rev. Lett. 102, 018101 (2009).

18）最近の外国論文リストはHawkes \& Spence (eds.) “Springer Handbook of Microscopy”（2020）に総括されている.

19）また拙書 “Electron Nano-imaging”, Springer（2017）および「走 査透過電子顕微鏡の物理」, 共立 (2018) の著者索引を利用し ていただければ幸甚です。

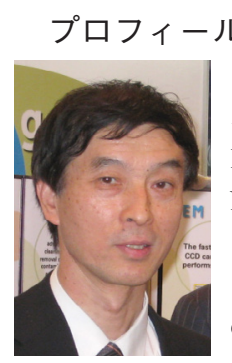

田中信夫 Nobuo TANAKA

名古屋大学未来材料システム研究所

Institute of Materials and Systems for Sustainability, Nagoya University, Japan Fine Ceramics Center

于 464-8309 名古屋市千種区不老町 1

1 Furo-cho, Chikusa-ku, Nagoya 464-8309, Japan

e-mail: ntanaka@nagoya-u.jp

最終学歴：名古屋大学工学研究科博士課程

博士 (工学)

専門分野：ナノ科学, 電子顕微鏡学, 電子線結 晶学

現在の研究テーマ: 環境電子顕微鏡法 